Editorial

\title{
Climate Change, Climatic Extremes, and Human Societies in the Past
}

\author{
Harry F. Lee ${ }^{(D)}$ \\ Department of Geography and Resource Management, The Chinese University of Hong Kong, Shatin, \\ New Territories, Hong Kong, China; harrylee@cuhk.edu.hk
}

Received: 7 July 2020; Accepted: 17 July 2020; Published: 20 July 2020

check for updates

\section{Introduction}

More people appreciate the importance of global sustainability. This is evidenced by a growing number of quantitative studies investigating the connection between climate change and human societies. Given this background, the Atmosphere Special Issue "Climate Change, Climatic Extremes, and Human Societies in the Past" aims to highlight the major aspects of the climate-society nexus in ancient and recent human history. There are eight papers in this Special Issue based on quantitative approaches which illustrate different forms of the climate-society nexus in ancient (two papers), historical (three papers), and contemporary periods (three papers).

\section{Temporal Coverage of this Special Issue}

\subsection{Ancient Periods}

Regarding ancient periods, the interconnection among climate, agriculture, and human societies is assessed. Li et al. [1] review archaeobotanical evidence from Neolithic sites in China and show that rice was primarily cultivated in the Yangtze River valley and its southern edge, while millet cultivation occurred in northern China circa 9000-7000 BP. Millet- and rice-based agriculture intensified and expanded during 7000-5000 BP. In 5000-4000 BP, rice agriculture continued to develop in the Yangtze River valley, and millet cultivation moved gradually westwards. Meanwhile, mixed agriculture based on both millet and rice developed along the border between the North and South. Climate-induced changes in vegetation and the environment played a significant role in agricultural development from 7000-6000 BP, while precipitation was crucial in shaping the distinct regional patterns of Chinese agriculture from 6000-4000 BP.

While climate and agriculture were closely connected in ancient times, the social dynamics in human societies were also thought important, significantly mediating the climate-agriculture connection. Wang et al. [2] base their paper on the human bone fragments obtained from the site of Xiaohucun, dated to the late Shang Dynasty (ca. 1250-1046 BC) in China, together with the isotopic analysis of collagen, to illustrate the connections between social status and diet. Those elite members probably consumed more animal protein such as horses, pigs, donkeys, and sheep/goats than the common people in the late Shang Dynasty.

\subsection{Historical Periods}

Regarding historical periods, various positive checks such as wars, famines, and epidemics are examined in this Special Issue. The common theme of the associated papers is to reveal the non-linear and complex relationship between climate change and the positive checks in historical China and pre-industrial Europe. Zhang et al. [3] employ Emerging Hot Spot Analysis to examine war hot spots in China from 1-1911. They show that war hot spots were generally located in the Loess Plateau and 
the North China Plain during warm and wet periods, but in the Central Plain, the Jianghuai area, and the lower reaches of the Yangtze River during cold and dry periods. Furthermore, the hot spots for agri-nomadic warfare had the abovementioned trends, while rebellion hot spots expanded outward during warm and wet phases and compressed inward during cold and dry phases.

Zhai et al. [4] investigate the social responses to the North China Famine of 1876-1879, which was brought on by extreme drought. They show that famine-related migration tended to be spontaneous and short-distanced, with the flow mainly spreading to the surrounding areas and towns. Furthermore, relief-money and grain from the non-disaster areas were allocated to the disaster areas. Yet, such state administrated intervention disrupted the equilibrium of food markets in non-disaster regions, resulting in food price fluctuations there.

Yue and Lee [5] examine the relative impact of the direct and indirect impacts of climate change on plague outbreaks in Europe between 1347-1760 using Structural Equation Models. They found that all of the climatic impacts on plague outbreaks were indirect and were materialized through economic changes. They further demonstrated that temperature-induced economic changes triggered plague outbreaks in cold and wet periods, while precipitation-induced economic changes induced plague outbreaks in cold periods.

\subsection{Contemporary Periods}

Over more recent times, the papers in this Special Issue focus on weather-related phenomena which significantly affect human societies. The non-linear dynamics of those phenomena are also highlighted. The associated findings can help human societies to mitigate the adverse impacts of weather extremes better. Xiang et al. [6] base their paper on summer precipitation data and 130 circulation indexes of 34 national meteorological stations in Chongqing spanning 1961-2010, together with the decision tree and the stochastic forest algorithm, to build a new multi-factor model for summer precipitation in Chongqing. Moreover, the model is tested with precipitation data from 2011-2018. Results show that the new model outperforms previous single-factor models.

Zhou et al. [7] use temperature data over 1980-2012 together with the Correlation Dimension method to analyze the temperature dynamics in the Yangtze River Delta in China. They find that the temperature rose by $1.53{ }^{\circ} \mathrm{C}$ over this period and the temperature rose the fastest in densely populated urban areas. However, the temperature dynamics were more complicated in the sparsely populated areas when compared to densely populated urban areas. Moreover, the complexity of temperature dynamics increased along with the increase in temporal scale. Lastly, the interaction between economic activity and urban density had the most substantial influence on temperature.

Yuan et al. [8] investigate the coupling between soil moisture and air temperature over China spanning from 1980-2013 using an energy-based diagnostic process. They show that the soil moisture-temperature coupling is the highest in the transition zones between wet and dry climates (e.g., north-eastern China and part of the Tibetan Plateau). Furthermore, the coupling is stronger in spring, and varies greatly in different seasons over different climatic zones. The heatwaves of 2009 in North China and 2013 in Southeast China further reveal that regions having low soil moisture may enhance heat anomalies, which further strengthens the coupling between soil moisture and temperature.

\section{Conclusions}

In summary, this Special Issue contributes theoretical and methodological analyses of the climate-society nexus. However, the conceptualization of the climate-society nexus is not a binary one. The nexus should be contextualized, while interdisciplinary collaboration should be further sought for addressing the topic $[9,10]$. It is also worth noting that the climate-society nexus is also dependent on temporal and spatial scales, and research findings will be determined by the length of the study time span and the size of the study area [11-13]. The aim of this Special Issue is to facilitate a more fruitful discussion about the climate-society nexus. 
I am very thankful to my colleagues for their invaluable contributions and the reviewers for constructive comments and suggestions that helped to improve the papers. Furthermore, I thank the MDPI journal office for their excellent support in processing and publishing this Special Issue.

Funding: This study is supported by the Improvement on Competitiveness in Hiring New Faculties Funding Scheme (4930900) and Direct Grant for Research 2018/19 (4052199) of the Chinese University of Hong Kong.

Conflicts of Interest: The author declare no conflict of interest.

\section{References}

1. Li, R.; Lv, F.; Yang, L.; Liu, F.; Liu, R.; Dong, G. Spatial-temporal variation of cropping patterns in relation to climate change in Neolithic China. Atmosphere 2020, 11, 677. [CrossRef]

2. Wang, N.; Jia, L.; Si, Y.; Jia, X. Isotopic results reveal possible links between diet and social status in Late Shang Dynasty (ca. 1250-1046 BC) tombs at Xiaohucun, China. Atmosphere 2020, 11, 451.

3. Zhang, S.; Zhang, D.D.; Li, J. Climate change and the pattern of the hot spots of war in ancient China. Atmosphere 2020, 11, 378. [CrossRef]

4. Zhai, X.; Fang, X.; Su, Y. Regional interactions in social responses to extreme climate events: A case study of the North China Famine of 1876-1879. Atmosphere 2020, 11, 393. [CrossRef]

5. Yue, R.P.H.; Lee, H.F. Examining the direct and indirect effects of climatic variables on plague dynamics. Atmosphere 2020, 11, 388. [CrossRef]

6. Xiang, B.; Zeng, C.; Dong, X.; Wang, J. The application of a decision tree and stochastic forest model in summer precipitation prediction in Chongqing. Atmosphere 2020, 11, 508. [CrossRef]

7. Zhou, C.; Zhu, N.; Xu, J.; Yang, D. The contribution rate of driving factors and their interactions to temperature in the Yangtze River Delta Region. Atmosphere 2020, 11, 32. [CrossRef]

8. Yuan, Q.; Wang, G.; Zhu, C.; Lou, D.; Hagan, D.F.T.; Ma, X.; Zhan, M. Coupling of soil moisture and air temperature from multiyear data during 1980-2013 over China. Atmosphere 2020, 11, 25. [CrossRef]

9. Lee, H.F. Historical climate-war nexus in the eyes of geographers. Asian Geogr. 2020. [CrossRef]

10. Lee, H.F. Measuring the effect of climate change on wars in history. Asian Geogr. 2018, 35, 123-142. [CrossRef]

11. Dong, G.; Liu, F.; Chen, F. Environmental and technological effects on ancient social evolution at different spatial scales. Sci. China Earth Sci. 2017, 60, 2067-2077. [CrossRef]

12. Lee, H.F.; Fei, J.; Chan, C.Y.S.; Pei, Q.; Jia, X.; Yue, R.P.H. Climate change and epidemics in Chinese history: A multi-scalar analysis. Soc. Sci. Med. 2017, 174, 53-63. [CrossRef] [PubMed]

13. Lee, H.F. Cannibalism in northern China between 1470 and 1911. Reg. Environ. Chang. 2019, 19, $2573-2581$. [CrossRef]

(C) 2020 by the author. Licensee MDPI, Basel, Switzerland. This article is an open access article distributed under the terms and conditions of the Creative Commons Attribution (CC BY) license (http://creativecommons.org/licenses/by/4.0/). 